\title{
Appraisal Index System and Weights Determination for Green Campus
}

\author{
Bailu Ma ${ }^{1, a}$,Xiaoping Feng ${ }^{* 2, b}$, Xiaoxia Lu ${ }^{3, c}$, Chunping Wang ${ }^{4, d}$, Hui Guo ${ }^{5,}$ \\ e, Yilin Ding ${ }^{6, f}$
}

School of Environment and Civil Engineering, Jiangnan University, 1800 Lihu Avenue, Wuxi, China amabailu@foxmail.com, ${ }^{\text {bfxp_99@126.com }}$

Key words: Green campus, Index system, Analytic Hierarchy Process, weighted analysis.

Abstract: Positioned on sustainable development philosophy, aiming to build a concise and systematic appraisal index system for green campus, the paper builds the index system and hierarchy structure model from perspectives of planning and ecology, energy and resources, environment and health, operation and management, education and promotion and etc. It adopts Analytic Hierarchy Process to analyze each factors' weights in the appraisal system thus providing a measurable analytic method for the appraisal of green campus deployment.

\section{Introduction}

Green campus was first mentioned in 1996 < The Action Outline of National Environmental promotion and education $>$, it put stress on placing environmental protection sense and actions into schools' overall management, education, teaching \& learning and construction activities, and guiding teachers and students to pay attention to environment issues. Facing the pressing needs of talents and scientific technologies in the deployment process of sustainable development strategies as well as the realistic needs of higher education's sustained development, colleges should play critical roles in knowledge innovation, sustained development and environmental education. "11 In order to facilitate green campus development, a complete set of appraisal index system is needed in China for evaluation and guidance. The appraisal index system is supposed to embody special characteristics of education industry, to reflect the injected various resources and the relationship between different aspects, layers, forms and effects in the construction process. The green campus appraisal should apply a method that combines qualitative and quantitative indexes, adopts relatively unified criterion and suitable weights so as to make the quantitative calculation easy and meanwhile reflect various indexes' status and functions thus improving the appraisal's precision and its conclusion's objectiveness.

\section{Establishing appraisal index system for green buildings}

\section{Basic principles of building index system}

Scientific principle

Scientific nature is an important principle of building green campus's appraisal system, the appraisal indexes should be reached by theoretical knowledge applied analysis and from an objective angle. Firstly, pay attention to combining the theories and realities, define appraisal indexes' concepts as well as extension, avoid overlaps of indexes. Next, appraisal indexes' concepts must be clear and specific with scientific significance so as to ensure the appraisal's scientific nature and reliability, thus enabling the system to have universal applicability. 


\section{Systematic principle}

Green campus appraisal index system is an organic whole formed by many complementary indexes and according to defined hierarchy structure. When design the index system, those that can comprehensively represent green campus construction and development aspects should be selected. In the hierarchy structure, every appraisal index represents the affiliation of each hierarchy, thus enabling horizontal and vertical irritation analysis of the indexes in the system, the indexes should be mutually independent and interconnected.

2. Operational principle

The operational principle requires finalized index system can be applied and executed very well. The key purpose of operability is to guide and standardize practices, it is a concrete deployment and implementation of theory construction. The requirements are when selecting appraisal indexes, pay attention to proportional relationship of subjective and objective indexes so it is easy to gather and collect indexes. Considerations should also be given to the appraisal indexes' sensitivity and reliability, hence selected indexes can precisely make evaluations on colleges.

3. Representative principle

Representative principle requires the selected indexes to highlight the subject's features during the evaluation process for green campus. Based on the theories of sustainable development, environmental ecology and economic applicability, to select representative indexes that can lead the construction of colleges' green campus.

\section{Hierarchy structure of the appraisal index system for green campus}

Hierarchy structure of the appraisal index system refers to affiliation between various indexes. Firstly, define the research object's target hierarchy, then set up several specific sub targets under the target hierarchy (i.e. intermediate hierarchy), the sub targets can be split into more concrete indexes, thus forming up an organic hierarchy structure for green campus and a system in which the indexes' relationship is clear. 
Table 1: index system for green campus

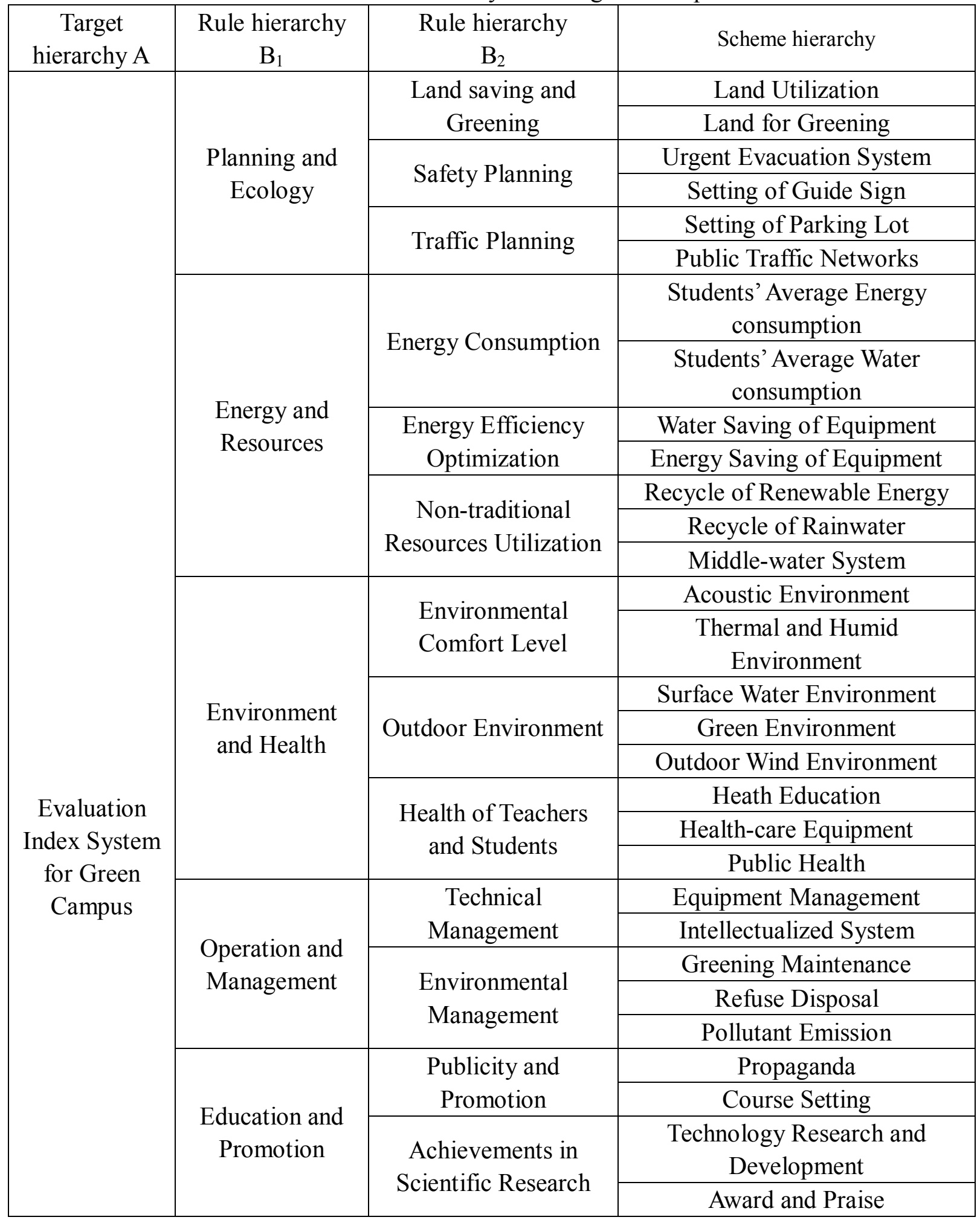

\section{Target hierarchy}

Target hierarchy is an overall evaluation of green campus: the green campus's general environmental protection, energy saving and sustained development status.

2. Rule hierarchy

Rules hierarchy is a summary of affecting factors on green campus including planning and ecology, energy and resources, environment and health, operation and management, education and promotion and the like affecting factors. 


\section{Scheme hierarchy}

Scheme hierarchy stays at the bottom of the hierarchy structure, it is a refinement of its above layer called intermediate hierarchy and is a more specific expression of affecting factors on green campus. Constant refinement enables every index to be measurable, can reflect overall status more detailly and comprehensively.

\section{Analysis of the rule hierarchy}

1. Planning and ecology

The index is used to evaluate the overall planning and ecological environment of campus. Campus planning is a determinant factor to campus' future plasticity and overall style, including land saving and greening, safety planning, traffic planning and filed construction.

2. Energy and Resources

The index of energy and resources is applied to assess campus' overall effect of energy saving. In respect to utilization of energy and resources, institutions of higher learning are supposed to keep in line with the principle of sustainable development and serve as an example to influence their surroundings in the aspect of energy saving and utilization of sustainable resources.

3. Environment and health

The index is adopted to evaluate the overall environment of campus. Campus environment will greatly impact the comfort of the major groups, teachers and students. Favorable campus environment is able to provide both teachers and students with pleasant feelings and has positive effects on their working and learning.

4. Operation and management

As a whole, campus needs to be equipped with a complete operation and management system, which is roughly divided into system management, technical management and environment and used to observe operation and management effect and whether management system is complete.

5. Education and promotion

During constructing green campus, institutions of higher learning should get the utmost out of its major functions and features, formulate related regulations and policies, implement education and promotion, research and popularize relevant results in scientific research so as to push forward nationwide construction of green campus.

\section{Basic theory of Analytic Hierarchy Process}

Analytic Hierarchy Process short named as AHP is about decomposing decisions invariably associated factors into targets, rules and schemes, then make qualitative and quantitative analysis for decision making. The specific process is building judgement matrix for every identified hierarchy, do consistency inspection and get the feature vector, finally define prioritized weighting of every subordinate layers toward their upper layers, i.e. the sum up of all subordinate layers weighting equals to the upper layer's weighting. After summarizing all layers, final weight of every scheme for the overall target can be determined, the one with highest weight is the best scheme.

Analytic Hierarchy Process is a decision-making method with multiple principles that are easy, agile and practical and able to do quantitative analysis on qualitative problems. ${ }^{\mathbf{I} 3 \mathbf{I}}$ Its strength is that it views the entire system as a whole without neglecting any factor's impact, and the setting of every weight can eventually impact the results in a direct or indirect way, and the impact degree of every factor in every hierarchy is quantitative. 


\section{Hierarchy judgement matrix}

Every factor's weight reflects the important degree of it in the green campus appraisal system, generally 1 9 scaling method is applied. Assume in a certain hierarchy, there's $\mathrm{n}$ factors, $\mathrm{X}=\{\mathrm{x} 1, \mathrm{x} 2, \ldots, \mathrm{xn}\}$, conduct paired comparison of factors and form the judgement matrix.

Target hierarchy A 's judgement matrix toward rule hierarchy B

\begin{tabular}{c|c|c|c|c|c}
$\mathrm{A}$ & $\mathrm{B}_{1}$ & $\mathrm{~B}_{2}$ & $\mathrm{~B}_{3}$ & $\mathrm{~B}_{4}$ & $\mathrm{~B}_{5}$ \\
\hline $\mathrm{B}_{1}$ & $a_{11}$ & $a_{12}$ & $a_{13}$ & $a_{14}$ & $a_{15}$ \\
\hline $\mathrm{B}_{2}$ & $a_{21}$ & $a_{22}$ & $a_{23}$ & $a_{24}$ & $a_{25}$ \\
\hline $\mathrm{B}_{3}$ & $a_{31}$ & $a_{32}$ & $a_{33}$ & $a_{34}$ & $a_{35}$ \\
\hline $\mathrm{B}_{4}$ & $a_{41}$ & $a_{42}$ & $a_{43}$ & $a_{44}$ & $a_{45}$ \\
\hline $\mathrm{B}_{5}$ & $a_{51}$ & $a_{52}$ & $a_{53}$ & $a_{54}$ & $a_{55}$
\end{tabular}

Table 2: Importance levels of each index

\begin{tabular}{cl}
\hline Scores & \multicolumn{1}{c}{ Meanings } \\
\hline $\mathbf{1}$ & $\begin{array}{l}\text { Means comparing two factors, they are equally important } \\
\text { Means comparing two factors, the former one is slightly more important } \\
\text { than the later one. } \\
\text { Means comparing two factors, the former one is moderately more } \\
\text { important than the later one. } \\
\text { Means comparing two factors, the former one is much more important } \\
\text { than the later one. } \\
\text { Means comparing with two factors, the former one is absolutely more } \\
\text { important than the later one. }\end{array}$ \\
\hline $\mathbf{9}$ &
\end{tabular}

\section{Consistency Inspection}

1. Single ordering and consistency inspection

Because the importance degree's value of every index is defined by experts, the judgment matrix has certain subjective nature, therefore need to do consistency inspection on the matrix i.e. to calculate the deviation index C.I.:

$$
\text { C.I. }=\frac{\lambda_{\max }-n}{n-1}
$$

According to different orders in the judgment matrix to reach average random consistency index R. I.

\begin{tabular}{lllllllll}
\hline 1 & 2 & 3 & 4 & 5 & 6 & 7 & 8 & 9 \\
\hline 0.00 & 0.00 & 0.58 & 0.90 & 1.12 & 1.24 & 1.32 & 1.14 & 1.45 \\
\hline
\end{tabular}

Then random consistency index C. R.:

$$
C . R .=\frac{C . I .}{R . I .}
$$

When $\mathrm{CR}<0.1$, the consistency of the judgment matrix is considered acceptable, otherwise need to revise the matrix.

2. Hierarchy overall ordering and consistency inspection 


$$
C R=\frac{a_{1} C I_{1}+a_{2} C I_{2}+\mathrm{L}+a_{m} C I_{m}}{a_{1} R I_{1}+a_{2} R I_{2}+\mathrm{L}+a_{m} R I_{m}}
$$

Calculate the bottom toward top hierarchy's overall ordering vector, inspect $\mathrm{CR}<0.1$ by using overall ordering consistency ratio C.R.

If it gets passed, then make decisions according to the results indicated by overall ordering vector, otherwise need to reconsider the model or rebuild those matrixes to ensure C.R is bigger in paired comparison.

\section{Index system's weights analysis}

\section{Weighted analysis method}

Post-evaluation system for green campus, a multi-level and multi-factor evaluation system, not only involves energy saving and environmental protection of equipment inside campus, but reflects the main users' satisfaction with the overall operation of green campus. Therefore, to evaluate green campus is a comparatively blurry process difficult to be quantified accurately. In the determination of the weight, there are usually two categories - subjective empowerment evaluation method and objective empowerment evaluation method.

Compared with the objective empowerment evaluation method, the subjective empowerment evaluation method is more inclined to the experts through the experience to measure the relative importance of each index, to a certain extent and can reflect the needs of users. So the paper adopts the analytic hierarchy process in subject weighting evaluation method to determine weight. In addition, in order to improve accuracy of calculation, the case applies analytic hierarchy process software, YAAHP, as a tool to calculate the weight and gains the weight of all levels of indexes as below.

Before undertaking analytic hierarchy process, in order to ensure every index's importance level is relatively reasonable, we released questionnaires to experts, after statistics we got every index's importance degree values, after paired comparison we were able to build judgment matrix.

\section{AHP defines index's weighting}

Take outdoor environment for example, a judgment matrix is built on the basis of importance degree value derived from questionnaires.

$$
\mathrm{A}=
$$

(1)Classify every column of the judgment matrix $M_{i=1} \prod_{1}^{j} a_{i j}, \overline{W_{i}}=\sqrt[3]{M_{i}}$, wi= $M_{i j} \sum^{\sum_{1}^{3} \bar{W}_{i}}$

$\mathrm{M} 1=0.5, \quad \overline{\mathrm{W}_{1}}=0.7937, \quad \mathrm{w} 1=0.25$

$\mathrm{M} 2=4, \quad \overline{\mathrm{W}_{2}}=1.5874, \quad \mathrm{w} 2=0.5$;

$\mathrm{M} 3=0.5, \quad \overline{\mathrm{W}_{3}}=0.7937, \quad \mathrm{w} 3=0.25$ 
By calculation, the outdoor environment's weight is 0.05 , final weight is: $\mathrm{W}=\{0.0125,0.0250,0.0125\}$.

(2) $\lambda_{\max }$ calculation. ${ }^{\lambda}{ }_{\max } \mathrm{W}=\mathrm{AW}$. Put into data and can get the judgment matrix's $\lambda_{\max }=3.000$ 。

(3) Inspect for consistency. ${ }_{\max }=3.000, \quad \mathrm{Cl}=\frac{\lambda_{\max }-n}{n-1}, \mathrm{n}=3, \mathrm{CI}=0$ 。

$\mathrm{CR}=\mathrm{CI} / \mathrm{RI}=0.000<0.10$, Meet consistency requirements.

Or alternatively put index's judgment matrix into software to calculate, the software can automatically calculate every index's weight and do consistency inspection.

The determination of intermediate hierarchy's indexes also applies the same method, hereby a summary of various indexes' weights.

Table 3: Various Indexes' Weights

\begin{tabular}{|c|c|c|c|c|c|}
\hline First-level index & Weight & $\begin{array}{l}\text { Second-level } \\
\text { index }\end{array}$ & Weight & Third-level index & Weight \\
\hline \multirow{6}{*}{$\begin{array}{l}\text { Planning and } \\
\text { Ecology }\end{array}$} & \multirow{6}{*}{0.2000} & \multirow{2}{*}{$\begin{array}{l}\text { Land saving and } \\
\text { Greening }\end{array}$} & \multirow{2}{*}{0.0500} & Land Utilization & 0.0125 \\
\hline & & & & Land for Greening & 0.0375 \\
\hline & & \multirow{2}{*}{ Safety Planning } & \multirow[t]{2}{*}{0.1000} & $\begin{array}{l}\text { Urgent Evacuation } \\
\text { System }\end{array}$ & 0.0500 \\
\hline & & & & Setting of Guide Sign & 0.0500 \\
\hline & & \multirow[b]{2}{*}{ Traffic Planning } & \multirow[b]{2}{*}{0.0500} & Setting of Parking Lot & 0.0250 \\
\hline & & & & $\begin{array}{c}\text { Public Traffic } \\
\text { Networks }\end{array}$ & 0.0250 \\
\hline \multirow{7}{*}{$\begin{array}{l}\text { Energy and } \\
\text { Resources }\end{array}$} & \multirow{7}{*}{0.2500} & \multirow{2}{*}{$\begin{array}{c}\text { Energy } \\
\text { Consumption }\end{array}$} & \multirow{2}{*}{0.0833} & $\begin{array}{c}\text { Students' Average } \\
\text { Energy consumption }\end{array}$ & 0.0417 \\
\hline & & & & $\begin{array}{l}\text { Students' Average } \\
\text { Water consumption }\end{array}$ & 0.0417 \\
\hline & & \multirow{2}{*}{$\begin{array}{c}\text { Energy Efficiency } \\
\text { Optimization }\end{array}$} & \multirow{2}{*}{0.0833} & $\begin{array}{c}\text { Water Saving of } \\
\text { Equipment }\end{array}$ & 0.0417 \\
\hline & & & & $\begin{array}{l}\text { Energy Saving of } \\
\text { Equipment }\end{array}$ & 0.0417 \\
\hline & & \multirow{3}{*}{$\begin{array}{l}\text { Non-traditional } \\
\text { Resources } \\
\text { Utilization }\end{array}$} & \multirow{3}{*}{0.0833} & $\begin{array}{c}\text { Recycle of Renewable } \\
\text { Energy }\end{array}$ & 0.0458 \\
\hline & & & & Recycle of Rainwater & 0.0200 \\
\hline & & & & Middle-water System & 0.0175 \\
\hline
\end{tabular}


Table 3 Continued: Various Indexes' Weights

\begin{tabular}{|c|c|c|c|c|c|}
\hline \multirow{8}{*}{$\begin{array}{c}\text { Environment and } \\
\text { Health }\end{array}$} & \multirow{8}{*}{0.2500} & \multirow[b]{2}{*}{$\begin{array}{l}\text { Environmental } \\
\text { Comfort Level }\end{array}$} & \multirow[b]{2}{*}{0.0500} & Acoustic Environment & 0.0250 \\
\hline & & & & $\begin{array}{l}\text { Thermal and Humid } \\
\text { Environment }\end{array}$ & 0.0250 \\
\hline & & \multirow{3}{*}{$\begin{array}{l}\text { Outdoor } \\
\text { Environment }\end{array}$} & \multirow{3}{*}{0.0500} & $\begin{array}{l}\text { Surface Water } \\
\text { Environment }\end{array}$ & 0.0125 \\
\hline & & & & $\begin{array}{c}\text { Greening } \\
\text { Environment }\end{array}$ & 0.0250 \\
\hline & & & & $\begin{array}{l}\text { Outdoor Wind } \\
\text { Environment }\end{array}$ & 0.0125 \\
\hline & & \multirow{3}{*}{$\begin{array}{l}\text { Health of Teachers } \\
\text { and Students }\end{array}$} & \multirow{3}{*}{0.1000} & Heath Education & 0.0390 \\
\hline & & & & $\begin{array}{l}\text { Health-care } \\
\text { Equipment }\end{array}$ & 0.0491 \\
\hline & & & & Public Health & 0.0619 \\
\hline \multirow{5}{*}{$\begin{array}{c}\text { Operation and } \\
\text { Management }\end{array}$} & \multirow{5}{*}{0.2000} & \multirow{2}{*}{$\begin{array}{c}\text { Technical } \\
\text { Management }\end{array}$} & \multirow{2}{*}{0.1000} & $\begin{array}{c}\text { Equipment } \\
\text { Management }\end{array}$ & 0.0250 \\
\hline & & & & $\begin{array}{l}\text { Intellectualized } \\
\text { System }\end{array}$ & 0.0750 \\
\hline & & \multirow{3}{*}{$\begin{array}{l}\text { Environmental } \\
\text { Management }\end{array}$} & \multirow{3}{*}{0.1000} & Greening Maintenance & 0.0500 \\
\hline & & & & Refuse Disposal & 0.0250 \\
\hline & & & & Pollutant Emission & 0.0250 \\
\hline \multirow{4}{*}{$\begin{array}{c}\text { Education and } \\
\text { Promotion }\end{array}$} & \multirow{4}{*}{0.1000} & \multirow{2}{*}{$\begin{array}{l}\text { Publicity and } \\
\text { Promotion }\end{array}$} & \multirow{2}{*}{0.0500} & Propaganda & 0.0250 \\
\hline & & & & Course Setting & 0.0250 \\
\hline & & \multirow{2}{*}{$\begin{array}{l}\text { Achievements in } \\
\text { Scientific } \\
\text { Research }\end{array}$} & \multirow[t]{2}{*}{0.0500} & $\begin{array}{c}\text { Technology Research } \\
\text { and Development }\end{array}$ & 0.0333 \\
\hline & & & & Award and Praise & 0.0167 \\
\hline
\end{tabular}

\section{Hierarchy overall ordering}

Summarize three hierarchy's weights, get the final hierarchy's overall ordering as below form shown: - 
Table 4: Overall ordering of the final hierarchy

\begin{tabular}{|c|c|c|c|c|c|}
\hline Index & Weight & Ranking & Index & Weight & Ranking \\
\hline Land Utilization & 0.0125 & 28 & Heath Education & 0.0390 & 12 \\
\hline Land for Greening & 0.0375 & 13 & $\begin{array}{l}\text { Health-care } \\
\text { Equipment }\end{array}$ & 0.0491 & 6 \\
\hline $\begin{array}{l}\text { Urgent Evacuation } \\
\text { System }\end{array}$ & 0.0500 & 3 & Public Health & 0.0619 & 2 \\
\hline Setting of Guide Sign & 0.0500 & 3 & $\begin{array}{c}\text { Equipment } \\
\text { Management }\end{array}$ & 0.0250 & 15 \\
\hline $\begin{array}{c}\text { Setting of Parking } \\
\text { Lot }\end{array}$ & 0.0250 & 15 & $\begin{array}{l}\text { Intellectualized } \\
\text { System }\end{array}$ & 0.0750 & 1 \\
\hline $\begin{array}{c}\text { Public Traffic } \\
\text { Networks }\end{array}$ & 0.0250 & 15 & $\begin{array}{c}\text { Greening } \\
\text { Maintenance }\end{array}$ & 0.0500 & 3 \\
\hline $\begin{array}{c}\text { Students' Average } \\
\text { Energy consumption }\end{array}$ & 0.0417 & 8 & Refuse Disposal & 0.0250 & 15 \\
\hline $\begin{array}{l}\text { Students' Average } \\
\text { Water consumption }\end{array}$ & 0.0417 & 8 & $\begin{array}{l}\text { Pollutant } \\
\text { Emission }\end{array}$ & 0.0250 & 15 \\
\hline $\begin{array}{l}\text { Water Saving of } \\
\text { Equipment }\end{array}$ & 0.0417 & 8 & Propaganda & 0.0250 & 15 \\
\hline $\begin{array}{l}\text { Energy Saving of } \\
\text { Equipment }\end{array}$ & 0.0417 & 8 & Course Setting & 0.0250 & 15 \\
\hline $\begin{array}{c}\text { Recycle of } \\
\text { Renewable Energy }\end{array}$ & 0.0458 & 7 & $\begin{array}{c}\text { Technology } \\
\text { Research and } \\
\text { Development }\end{array}$ & 0.0333 & 14 \\
\hline Recycle of Rainwater & 0.0200 & 25 & Award and Praise & 0.0167 & 27 \\
\hline Middle-water System & 0.0175 & 26 & $\begin{array}{l}\text { Surface Water } \\
\text { Environment }\end{array}$ & 0.0125 & 28 \\
\hline $\begin{array}{c}\text { Acoustic } \\
\text { Environment }\end{array}$ & 0.0250 & 15 & $\begin{array}{c}\text { Greening } \\
\text { Environment }\end{array}$ & 0.0250 & 15 \\
\hline $\begin{array}{c}\text { Thermal and Humid } \\
\text { Environment }\end{array}$ & 0.0250 & 15 & $\begin{array}{l}\text { Outdoor Wind } \\
\text { Environment }\end{array}$ & 0.0125 & 28 \\
\hline
\end{tabular}

We can tell from the form green campus appraisal result is mostly affected by the index called intelligent system followed by the public hygiene.

\section{Conclusion}

In this paper, the Analytic Hierarchy Process method is used to determine the weight of the green campus appraisal, while ensuring the objectivity, makes the evaluation process more considerate 
about the users' subjective will. Through the scores of different schools about the index, the corresponding score can be obtained after the calculation, so that the evaluation of green campus can be quantified. It meets the demand of different colleges and universities on the green campus construction management and maintenance requirements, and has great significance in evaluation of green campus and its promotion.

\section{References}

[1] Wang Min. Green University and Sustainable Development Education. [M]. Beijing: Geological Publishing House, 2006: $1 \sim 67$.

[2] Gan Yufeng. Study on POE of the Building Energy Saving Demonstration Project[D].Master 's degree thesis of Chongqing University,2011.

[3] Deng Xue, Li Jiaming, Zeng Haojian, Chen Junyu, Zhao Junfeng. Research on Computation Methods of AHP Weight Vector and Its Application. [J] . Mathematics in Practice and Theory,2012,42(7).

[4] He Xin, Gao Fu'an. Application of AHP - Fuzzy Comprehensive Evaluation Method in Performance Evaluation of TV Channel Sector. [J] Advanced Television Engineering.2013(1):111. 